\title{
sudska praksa
}

Slobodan Sremčev*

\section{SUDSKA PRAKSA PRIVREDNOG SUDA U NOVOM SADU - IZBOR}

\section{Odsustvo stranke i odrăavanje ročišta za glavnu raspravu \\ - Član 311 stav 1 Zakona o parničnom postupku -}

(Sl. glasnik RS br. 72/2011, 49/2013 - odluka US, 74/2013 - odluka US $i$ 55/2014)

Okolnost da je pre početka rasprave pristupilo lice koje se predstavilo kao zakonski zastupnik tuženog i koje je tražilo odlaganje ročišta jer treba da da izjavu pred krivičnim sudom, ne obavezuje sud da po istom postupi i ročište odloži.

\section{Iz obrazloženja:}

Prvostepeni sud je, u situaciji kada je pre početka rasprave pristupilo lice koje se predstavilo kao zakonski zastupnik tuženog i tražio odlaganje ročišta, jer je trebalo da da izjavu pred krivičnim sudom, održao ročište u odsustvu uredno pozvanog tuženog, konstatovao da se radi o sporu male vrednosti, izveo priložene dokaze i raspravu zaključio.

Prema drugostepenoj odluci, tuženom je data mogućnost da raspravlja pred sudom, jer je poziv za ročište za glavnu raspravu blagovremeno i uredno primio, tuženi nije blagovremeno tražio odlaganje ročišta iako je za to imao dovoljno vremena, već je izvršio izbor postupka u kome će učestvovati.

(presuda Privrednog apelacionog suda 5 Pž 9797/13 od 12.03.2015. godine, presuda Privrednog suda u Novom Sadu P. 2027/2012 od 05.04.2013. godine)

* Predsednik Privrednog suda u Novom Sadu. 


\section{Srazmernost između visine duga $i$ vrednosti predmeta obezbeđenja}

- Članovi 20 stav 7 i 261 Zakona o izvršenju i obezbeđenju -

Sl. glasnik RS br. 31/2011, 99/2011 - dr. zakon, 109/2013 - odluka US, $55 / 2014$ i 139/2014

Prilikom odlučivanja o predlogu za određivanje privremene mere potrebno je ceniti srazmernost između visine novčanog potraživanja obuhvaćenog tužbenim zahtevom i vrednosti predmeta obezbeđenja.

Iz obrazloženja:

U sporu po tužbi privrednog subjekta protiv tuženog 1. reda privrednog subjekta i tuženog 2. reda fizičkog lica sud je doneo rešenje kojim je usvojio predlog tužioca za određivanje privremene mere u odnosu na tuženog 2. reda, te je istom zabranjeno da otuđi i optereti nepokretnosti u njegovoj svojini. U daljem toku postupka tužilac je predložio određivanje privremene mere tako što bi tuženom 1. reda bilo zabranjeno da otuđi i optereti pravo svojine na idealnom delu određene nepokretnosti. Sud je predlog tužioca usvojio, ali je to rešenje ukinuto od strane drugostepenog suda.

Prema drugostepenoj odluci, drugostepeni sud u svemu prihvata razloge prvostepenog suda koje je naveo u prilog postojanja dovoljnog stepena verovatnosti osnovanosti potraživanja obuhvaćenog tužbenim zahtevom za određivanje privremene mere, kao i opasnosti za osujećenje naplate potraživanja, ali da prvostepeni sud prilikom odlučivanja nije cenio srazmernost između visine novčanog potraživanja obuhvaćenog tužbenim zahtevom i vrednosti predmeta obezbeđenja, što je dužan ceniti u skladu sa članom 20 stav 7 Zakona o izvršenju i obezbeđenju.

(rešenje Privrednog apelacionog suda 4 Pž 1028/15 od 08.04.2005; rešenje Privrednog suda u Novom Sadu P. 969/2014 od 06.03.2015. godine) 


\section{Izmakla dobit}

\section{- Član 189 stav 1 i stav 3 Zakona o obligacionim odnosima-}

(Sl. list SFRJ br. 29/78, 39/85, 45/89 - odluka USJ i 57/89, Sl. list SRJ br. 31/93 i Sl. list SCG br. 1/2003 - Ustavna povelja)

Pravo na naknadu izmakle dobiti oštećeni ima samo ako je prema onome što se u životu redovno dešava ili prema posebnim okolnostima slučaja izvesno da bi on tu korist ostvario da šteta nije nastupila. Kao relevantan ne uzima se dobitak za koji se po subjektivnim procenama oštećenog pretpostavlja da će nastupiti već dobitak koji bi svakako nastupio da nije bilo štete.

\section{Iz obrazloženja:}

Prema činjeničnom stanju, tužilac je vlasnik autobusa oštećenog u saobraćajnoj nezgodi, a tuženi je osiguravač vozila koje je skrivilo saobraćajnu nezgodu u kojoj je oštećeno vozilo tužioca. Tužilac traži naknadu štete u vidu vrednosti izgubljenih autodana za period od saobraćajne nezgode do dana kada mu je tuženi isplatio naknadu stvarne štete na vozilu, odnosno naknadu za njegovu popravku.

Prema drugostepenoj odluci, pravilno je stanovište prvostepenog suda da tužilac za period za koji nije mogao da koristi oštećeno vozilo, ima osnova da potražuje naknadu štete u vidu izgubljene dobiti kao protivvrednost izgubljenih autodana, a sve iz razloga što je došlo do oštećenja vozila krivicom osiguranika tuženog.

Međutim, prvostepeni sud je propustio da da jasne razloge u pogledu optimalnog perioda vremena potrebnog za popravku autobusa i samim tim broj autodana za koje je tužilac bio sprečen da ostvari prihod, nemogućnošću upotrebe predmetnog vozila. Pri tom se kao relevantan datum do koga tužilac nije mogao da koristi predmetno vozilo ne može uzeti datum kada je tuženi isplatio naknadu za popravku autobusa, već datum kada je popravka izvršena i kada je tužilac imao mogućnost da preuzme vozilo i samim tim ga stavi u pogon. Uputstvo je drugostepenog suda da prvostepeni sud razjasni koliki je bio optimalni period za popravku predmetnog vozila, zatim kada je tužilac imao mogućnost da vozilo i preuzme i saglasno navedenom, za koliko autodana nije mogao da ostvari prihode, te da uz pravilnu primenu materijalnog prava donese novu na zakonu zasnovanu odluku.

(rešenje Privrednog apelacionog suda 8 Pž 6537/14 od 18.03.2005; presuda Privrednog suda u Novom Sadu P. 1735/12 od 03.06.2014. godine) 


\section{Dopuštenost ugovaranja visine stope ugovorne kamate u slučaju prekoračenja dozvoljenog minusa}

\section{- Članovi 277, 279 i 400 Zakona o obligacionim odnosima -}
(Sl. list SFRJ br. 29/78, 39/85, 45/89 - odluka USJ i 57/89, Sl. list SRJ br. 31/93 i Sl. list SCG br. 1/2003 - Ustavna povelja)

Ugovorne odredbe o ugovaranju visine kamatne stope u slučaju prekoračenja dozvoljenog minusa i na iznos prekoračenja dozvoljenog minusa, po svojoj pravnoj prirodi bi predstavljale dopušteno ugovaranje visine stope ugovorne kamate, kao cene kredita, posebno u situaciji činjenične tvrdnje tužioca da su kamatne stope kod drugih poslovnih banaka na istu vrstu ugovornog odnosa bile više, te posebno imajući u vidu da ovu činjeničnu tvrdnju tuženi do zaključenja glavne rasprave nisu osporili.

\section{Iz obrazloženja:}

Prema činjeničnom stanju, parnične stranke su bile u poslovnom odnosu tako što je tužilac sa tuženim 1. reda zaključio ugovor o okvirnom kreditu - dozvoljenom minusu na tekućem računu na određeni iznos na neodređeni rok sve dok korisnik ne prekrši odredbe ovog ili nekog drugog ugovora sa tužiocem ili dok korisnik ugovor pismeno ne otkaže. Korisnik se ugovorom saglasio i ovlastio banku da u slučaju prekoračenja po dozvoljenom minusu na njegovom tekućem računu obračunava i naplaćuje kamatu na nedozvoljeni minus (prekoračenje) u visini od $0,13 \%$ dnevno na vrednost prekoračenja uvećanu za ugovorene troškove. Tuženi 1. reda je korisnik kredita, tuženi 2. reda je jemac platac. Prvostepeni sud je na okolnost ukupnog potraživanja tužioca izveo dokaz veštačenjem od strane veštaka ekonomske struke koji je u pisanom mišljenju utvrdio dug tuženih na dan veštačenja $i$ to glavni dug i obračunatu kamatu od $0,13 \%$ dnevno sa stanjem na dan veštačenja.

Prvostepeni sud je obavezao tužene da tužiocu solidarno isplate iznos glavnog duga sa zakonskom zateznom kamatom od veštačenja do isplate, a odbio je zahtev tužioca u delu u kojem je tražio obračunatu kamatu po stopi od 0,13 dnevno, kao i za razliku tražene kamate od $0,13 \%$ dnevno na iznos glavnog duga od veštačenja do isplate.

Prema drugostepenoj odluci:

- Pogrešno je prvostepeni sud odbio zahtev tužioca za isplatu uglavničene 
kamate po stopi od $0,13 \%$ dnevno jer navedeni iznos predstavlja cenu za korišćenje kapitala, a ne kamatu zbog docnje u isplati glavnog duga. $\mathrm{Na}$ isplatu ovog iznosa tužilac ima pravo, te se ne može prihvatiti obrazloženje suda da se radi o nedopuštenom ugovaranju visine zatezne kamate.

- Pravilno je odbijen zahtev tužioca da mu se na ukupno dobijen iznos dalje dosudi ugovorena kamata od $0,13 \%$ dnevno i da mu se na dosuđeni iznos glavnice dosudi navedena kamata, jer tužilac na dobijeni iznos glavnog duga i obračunate ugovorene kamate dalje može sa uspehom da potražuje samo zakonsku zateznu kamatu. To proizlazi iz članova 277, 279 i 400 Zakona o obligacionim odnosima.

(presuda Privrednog apelacionog suda 5 Pž 3475/13 od 23.03.2015. godine, presuda Privrednog suda u Novom Sadu br. P. 1483/11 od 19.02.2013. godine)

\section{Obaveza osiguravača isplate naknade kod ugovora o osiguranju}

\section{- Član 919. Zakona o obligacionim odnosima -}

\section{(Sl. list SFRJ br. 29/78, 39/85, 45/89 - odluka USJ i 57/89, Sl. list SRJ br. 31/93 i Sl. list SCG br. 1/2003 - Ustavna povelja)}

Tužilac (ugovarač osiguranja) ispunio je svoju obavezu iz Ugovora o osiguranju i opštim uslovima, kada je izvestio o štetnom događaju organ unutrašnjih poslova i mesto događaja napustio uz odobrenje nadležnog organa.

Prema stanju u spisima predmet tužbenog zahteva jeste isplata naknade iz osiguranja. Po sprovedenom dokaznom postupku prvostepeni sud je utvrdio da su se parnične stranke i to tužilac kao ugovarač osiguranja, tuženi kao osiguravač i lizing privredno društvo kao vlasnik vozila i korisnik osiguranja nalazili u poslovnom odnosu po osnovu zaključenog ugovora o osiguranju - kasko osiguranju s tim da je lizing društvo ovlastilo tužioca kao ugovarača osiguranja da može vršiti sva prava iz osiguranja. Dalje je utvrđeno da je 12.07.2012. godine tužilac primetio da mu je oštećeno vozilo na parkingu u S., da je u skladu sa Uslovima osiguranja motornih i šinskih vozila koji je sastavni deo ugovora o kasko osiguranju, pozvao policiju, da je tom prilikom sačinjena službena beleška, da je na taj način u svemu postupio po ugovornim odredbama, da je popravku vozila u ovlašćenom servisu platio. Kod takvog stanja stvari pozivajući se na 
odredbe člana 897 i 901, stav 1 i člana 919 Zakona o obligacionim odnosima tužilac je zahtevao da mu tuženi plati novčani iznos popravke vozila, a tuženi nije sporio visinu i prvostepeni sud je zahtev usvojio.

Odluka prvostepenog suda je pravilna.

Prvostepeni sud je utvrdio da je tužilac u svemu postupio u skladu sa ugovorom odnosno opštim uslovima koji su sastavni deo ugovora. Suprotno žalbenim navodima tužilac jeste dokazao da je u celosti postupio u skladu sa opštim uslovima, a to proizilazi iz iskaza svedoka čije je iskaze sud u celini prihvatio i iskaza tužioca. Iz navedenih proizilazi da je tužilac prijavio štetu te da mu je od strane policijske uprave rečeno da vozilo doveze ispred policijske stanice odakle proizilazi da je postupio u skladu sa odredbama člana 6 opštih uslova i to tako što je odmah po saznanju nezgodu prijavio nadležnom organu unutrašnjih poslova, a da je mesto napustio uz odobrenje nadležnog organa jer mu je i rečeno da vozilo doveze u policijsku stanicu. Prednje čini žalbene navode žalioca neosnovanim.

(presuda Privrednog apelacionog suda 7. Pž.5071/15 od 25.05.2016. godine, presuda Privrednog suda u Novom Sadu P.437/13 od 08.07.2015. godine) 